\title{
Coupled blue and red light-emitting diodes therapy efficacy in patients with rosacea: two case reports
}

\author{
Elisabetta Sorbellini ${ }^{1 *}$, Maria Pia De Padova ${ }^{2}$ and Fabio Rinaldi ${ }^{1}$
}

\begin{abstract}
Background: Rosacea is a common inflammatory skin condition affecting approximately $5 \%$ of the world population. Therapeutic approaches to rosacea are focused on symptom suppression by means of antiinflammatory agents. More recently, photodynamic therapy, especially light-emitting diodes, has been introduced as a valid alternative to conventional therapy.

Case presentation: In the present work, we reported the efficacy and safety of light-emitting diodes therapy combining blue $(480 \mathrm{~nm})$ and red $(650 \mathrm{~nm})$ light for the treatment of two patients with papulopustular rosacea: a 22-year-old Caucasian woman and a 68-year-old Caucasian man.
\end{abstract}

Conclusions: This kind of treatment could represent an effective, safer, and well-tolerated approach for the treatment of such conditions.

Keywords: Rosacea, Light-emitting diodes, LED, Photodynamic therapy

\section{Background}

Acne rosacea, usually referred to as rosacea, is a common inflammatory skin condition affecting mainly the central face [1]. The term was introduced by Thomas Bateman in the nineteenth century as an acne variety [2]. Its typical manifestations are generalized erythema, telangiectasia, and edema, then papules and pustules or a combination of all $[3,4]$.

In 2004, the National Rosacea Society (NRS) Expert Committee published a report on the classification and staging of rosacea that defined the criteria for rosacea classification and grading according to primary and secondary descriptors [5]. Four subtypes of rosacea can be recognized on the basis of different morphological characteristics: erythematotelangiectatic, papulopustular, phymatous, and ocular $[5,6]$. The erythematotelangiectatic subtype is the most common one followed by papulopustular, phymatous and ocular types which are reported as less common [7]. Data from clinical practice show that patients often can harbor more than one

\footnotetext{
* Correspondence: elisabettasorbellinimd@gmail.com

${ }^{1}$ International Hair Research Foundation (IHRF), Milan, Italy

Full list of author information is available at the end of the article
}

rosacea subtype [7]; for this reason, incidence and prevalence evaluation is not simple. The latest data population, based on published data, refers to an incidence of 1.65 per 1000 persons per year [8] indicating approximately $5.46 \%$ of the worldwide population [9]. A stronger predominance for females was found for erythematotelangiectatic and papulopustular subtypes with a diagnosis, usually, after the fourth decade of life $[8,10]$.

The exact pathogenesis of rosacea remains unclear but the involvement of several external or endogenous factors is reported $[1,11]$. In fact, recent findings highlighted the role of predisposing factors such as genetic predisposition and association with other diseases [12]. Microbial stimuli, especially colonization, ultraviolet (UV) radiation, stress, and environmental changes are also recognized as triggering factors both for the development and worsening of rosacea [12-14]. Therefore, dysregulation of innate immunity via the expression of higher amounts of toll-like receptor 2 (TLR2) in the skin [15] and augmentation of the inflammatory cascade have been reported [16] as abnormal expression of cathelicidin antimicrobial peptides [17].

(c) The Author(s). 2020 Open Access This article is distributed under the terms of the Creative Commons Attribution 4.0 International License (http://creativecommons.org/licenses/by/4.0/), which permits unrestricted use, distribution, and reproduction in any medium, provided you give appropriate credit to the original author(s) and the source, provide a link to the Creative Commons license, and indicate if changes were made. The Creative Commons Public Domain Dedication waiver (http://creativecommons.org/publicdomain/zero/1.0/) applies to the data made available in this article, unless otherwise stated. 
More recently, rosacea and other skin diseases such as psoriasis and atopic dermatitis have been linked to intestinal dysbiosis $[18,19]$. Authors reported the role of intestinal dysbiosis in promoting inflammation and impairment of normal lymphocyte function, potentially perpetuating chronic, low-grade inflammation [20]. Therefore, the potential role of microorganisms in the pathogenesis of rosacea has been hypothesized [21]. Parodi and colleagues [22] reported a higher incidence of small intestinal bacterial overgrowth (SIBO) when patients with rosacea were compared to controls. Most interesting, microbial unbalancing of the skin microbiota on the skin has been linked to rosacea clinical manifestations [23], even though the direct correlation between microbiota composition on the skin and the incidence of the pathology is still under investigation.

More recently, in a NRS-supported study in twins, Zaidi and colleagues [24] reported the first evidence highlighting the correlation between the severity of rosacea and microbial dysbiosis on the skin, but further study is needed to determine the species involved.

Historically, therapeutic approaches to rosacea focused on symptom suppression by means of anti-inflammatory agents such as doxycycline [25-27], metronidazole [28], topical azelaic acid [11, 29], sodium sulfacetamide [11, 30], and calcineurin inhibitors [31]. The use of serine protease inhibitors is to be considered an emerging therapy in rosacea [32].

Several concerns surround the use of tetracyclines, especially as long-term treatment is often necessary. Although it is commonly prescribed at a sub-antimicrobial dose, gastrointestinal side effects and photosensitivity are not uncommon and the risk of antimicrobial resistance increases with higher doses [33, 34].

Although not yet approved for the treatment of rosacea, efficacy of a low dose of isotretinoin has been reported in patients with papulopustular rosacea subtype [35].

More recently, photodynamic therapy (PDT), especially light-emitting diodes (LED), has been introduced as a valid alternative to conventional therapy [36]. A few in vitro studies [37, 38] and a published in vivo study on patients with papulopustular rosacea with methyl ester aminolevulinate (MAL) coupled with PDT [39], reported efficacy of LEDs for treatment of rosacea.

\section{Case presentations}

\section{Case report 1}

A 22-year-old Caucasian woman presented to a dermatological clinic with a 5-year history of pink eruptions on her nose. She also reported a burning sensation. She was diagnosed as having papulopustular rosacea subtype, moderate grade, according to the classification and staging of rosacea developed by the NRS Expert Committee [5]. In the previous 2 years she was treated with two cycles of orally administered tetracycline (Lymecycline), $300 \mathrm{mg}$ per day, for 12 weeks. Systemic therapy was associated with metronidazole cream $1 \%$ for cycles of 6 months. In the last 6 months before the visit, she also submitted to $40 \%$ pyruvic acid peeling every 25 days, with poor response and continuous relapses. A combined and sequential plan of blue $(480 \mathrm{~nm} \pm 15 \mathrm{~nm}, 300 \mathrm{~J} /$ minute $)$ and red $(650 \pm 15 \mathrm{~nm}, 100 \mathrm{~J} /$ minute) LED therapy regimen was planned twice a week for a total of ten sessions. A quasi-monochromatic 120 LED system (Dermodinamica instrument, ELISOR Srl, Milan, Italy) was used for 15 minutes (each wavelength).

\section{Case report 2}

A 68-year-old Caucasian man presented with a 7-year history of papulopustular rosacea, moderate grade [5], which extended over the entire surface of his face. $\mathrm{He}$ had experienced extended relapses on his face once a year in the past 6-7 years. He was previously treated with two cycles of Lymecycline (tetracycline) at $300 \mathrm{mg}$ per day or azithromycin every 2 weeks in combination with $0.75 \%$ topical metronidazole. He was submitted to LED therapy twice a week for a total of ten sessions. Blue $(480 \mathrm{~nm} \pm 15 \mathrm{~nm}, 300 \mathrm{~J} /$ minute $)$ and red $(650 \pm 15$ $\mathrm{nm}, 300 \mathrm{~J} / \mathrm{minute}$ ) were sequentially irradiated for 15 minutes by means of LED system Dermodinamica ${ }^{\circ}$ (ELISOR Srl, Milan, Italy). The therapy was coupled with topical $15 \%$ azelaic acid.

\section{Outcome and follow-up}

Erythema, burning sensation, and itching were assessed using a visual scale grading $(0=$ no symptoms, $4=$ very severe). Erythema and papules were subjectively assessed by the dermatologist, whereas the intensity of itch and burning sensations was expressed by our patients. A good response was obtained for both patients after ten treatments with LEDs. Both patients reported a reduction of symptoms such as burning and itching. Also, a reduction of erythema and papules was observed after five sessions of LED therapy (Figs. 1b and 2b). Further improvement was observed at the end of treatment: ten sessions of LED therapy (Figs. 1c and 2c).

\section{Discussion and Conclusions}

Several therapeutic approaches are currently available for treating rosacea and they are mainly aimed at controlling disease symptoms [40, 41]. The therapeutic plan has to be adapted to the rosacea subtype and tailored 


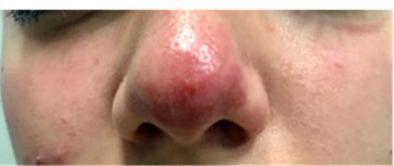

A

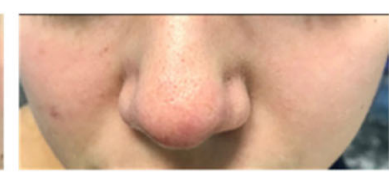

B

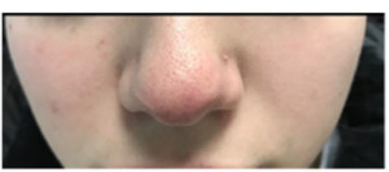

C

Fig. 1 Papulopustular rosacea on the nose of case report 1 at the base time (a), after five sessions (b), and after ten sessions (c) with coupled blue $(480 \mathrm{~nm})$ and red $(650 \mathrm{~nm})$ light-emitting diodes therapy

according to the dominant manifestations of the patient $[32,35]$. In general, the reduction of oral therapy in favor of topical or physical therapy is desirable in order to reduce side effects for patients and increasing the safety of treatment $[5,32]$.

The therapeutic approach described in this report aims at reporting the efficacy and safety of combined blue $(480 \mathrm{~nm} \pm 15 \mathrm{~nm})$ and red $(650 \pm 15 \mathrm{~nm})$ LED light-based therapy in patients affected by rosacea.

Previous research reported the efficacy of red and blue light coupled for the treatment of mild to moderate acne lesions [42, 43]. Blue light $(400-470 \mathrm{~nm})$, due to its lower penetration, is useful in such skin conditions related to the epidermis layer of the skin [44]; therefore, it is also able to interfere with human sebocytes proliferation [45]. On the other hand, red light $(630 \mathrm{~nm})$ is reported to have a significant effect on sebum production $[46,47]$. The benefits deriving from PDT using LEDs are not limited to its efficacy but are also related to its safety and tolerance by patients; therefore, its advantages can be extended to a broad range of dermatological conditions $[48,49]$.

In fact, PDT is routinely used by dermatologists in the treatment of moderate to severe acne vulgaris [50, 51] and perioral dermatitis [18]. Rosacea shares several features with other dermatological diseases, especially acne. In patients with acne, PDT has been supposed to act via modulation of the functionality of the pilosebaceous unit and this could probably also be applied to rosacea.

Previous to our work, several authors reported the efficacy of PDT therapy on patients with rosacea [36,
52-54]. Moreover, an in vitro study on rosacea-like mouse skin [55] reported the efficacy of LED at 630 and $940 \mathrm{~nm}$ on the down-regulation of key inflammatory mediators of rosacea, such as cathelicidin (LL37), TLR2, and kallikreins (KLKs). These results are in line with reported evidence on the efficacy of LED therapy also to interact with the host immune system. LEDs may also interact with skin microbiome [56-58] and this could also have as significant an impact on the etiopathogenesis of rosacea as on immune response modulation. A deeper knowledge of the implications of both gut and skin microbiome in rosacea is still needed; our recent research is aimed at evaluating the real effect of blue and red light LEDs on skin microflora in patients with rosacea and patients with acne.

In addition, the safety deriving from the use of LED devices encourages their ever-increasing use for the treatment of many dermatological conditions, including rosacea.

Nowadays, the treatment of patients with rosacea still represents a challenge for dermatologists. Conventional treatment of rosacea is either ineffective or results in the dissatisfaction of patients due to the need for continuous treatment.

The case reports presented in the current work show, for the first time, the usefulness of LED therapy combining blue and red light benefits for the treatment of patients with rosacea. This kind of treatment could represent an effective, safer, and welltolerated approach for the treatment of such kinds of condition.

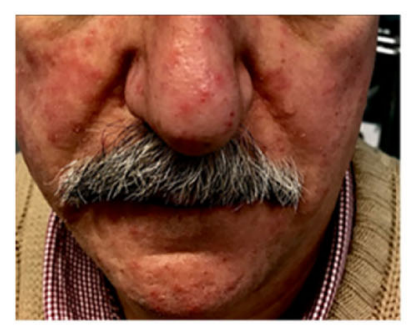

A

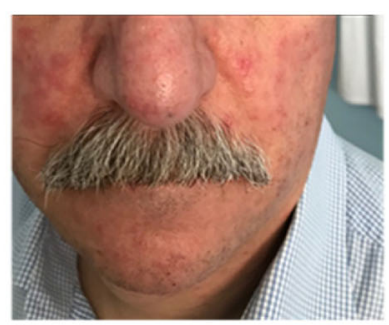

B

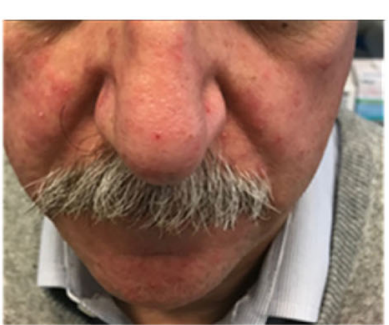

C

Fig. 2 Papulopustular rosacea with erythema and telangiectasias on the glabella, forehead, nose, cheeks, and chin of case report 2 at the base time (a), after five sessions (b), and after ten sessions (c) with coupled blue $(480 \mathrm{~nm})$ and red $(650 \mathrm{~nm})$ light-emitting diodes therapy 


\section{Acknowledgements}

All named authors meet the International Committee of Medical Journal Editors (ICMJE) criteria for authorship for this manuscript, take responsibility for the integrity of the work as a whole, and have given final approval for the version to be published.

\section{Authors' contributions}

Conceptualization, methodology and investigations: FR, ES, MD. Data curation and formal analysis: ES. Resources: ES and MD. Wrote the paper: FR and ES. All authors read and approved the final manuscript.

\section{Funding}

No funding or sponsorship was received for this study or publication of this article.

\section{Availability of data and materials Not applicable.}

\section{Ethics approval and consent to participate}

The study was approved by the Ethical Independent Committee for Clinical, not pharmacological investigation in Genoa (Italy) and in accordance with the ethical standards of the 1964 Declaration of Helsinki.

\section{Consent for publication}

Written informed consent was obtained from the patients for publication of this case report and any accompanying images. A copy of the written consent is available for review by the Editor-in-Chief of this journal.

\section{Competing interests}

The authors declare that they have no competing interests.

\section{Author details}

${ }^{1}$ International Hair Research Foundation (IHRF), Milan, Italy. ${ }^{2}$ Dermatology, Nigrisoli Private Hospital, Bologna, Italy.

Received: 5 June 2019 Accepted: 22 December 2019

\section{Published online: 28 January 2020}

\section{References}

1. Two AM, Wu W, Gallo RL, Hata TR. Rosacea: part I. Introduction, categorization, histology, pathogenesis, and risk factors. J Am Acad Dermatol. 2015;72(5):749-58. quiz 759-60. PMID: 25890455

2. Plewig G, Kligman AM. History of Acne and Rosacea. In: ACNE and ROSACEA. Berlin: Springer; 2000.

3. Steinhoff M, Schauber J, Leyden JJ. New insights into rosacea pathophysiology: a review of recent findings. J Am Acad Dermatol. 2013; 69(6 Suppl 1):S15-26. Review. PMID: 24229632

4. Tan J, Berg M. Rosacea: current state of epidemiology. J Am Acad Dermatol. 2013:69(6 Suppl 1):S27-35. Review. PMID: 24229634

5. Wilkin J, Dahl M, Detmar M, Drake L, Liang MH, Odom R, Powell F, National Rosacea Society Expert Committee. Standard grading system for rosacea: report of the National Rosacea Society Expert Committee on the classification and staging of rosacea. J Am Acad Dermatol. 2004;50(6):90712. PMID: 15153893

6. Wilkin J, Dahl M, Detmar M, Drake L, Feinstein A, Odom R, Powell F. Standard classification of rosacea: Report of the National Rosacea Society Expert Committee on the Classification and Staging of Rosacea. J Am Acad Dermatol. 2002:46(4):584-7. PMID: 11907512

7. Berg M, Lidén S. An epidemiological study of rosacea. Acta Derm Venereol. 1989;69(5):419-23. PMID: 2572109

8. Spoendlin J, Voegel JJ, Jick SS, Meier CR. A study on the epidemiology of rosacea in the U.K. Br J Dermatol. 2012;167(3):598-605. Epub 2012 Jul 23. PMID: 22564022

9. Gether L, Overgaard LK, Egeberg A, Thyssen JP. Incidence and prevalence of rosacea: a systematic review and meta-analysis. Br J Dermatol. 2018;179(2): 282-9. Epub 2018 May 31. Review. PMID: 29478264

10. Rainer BM, Fischer AH, Luz Felipe da Silva D, Kang S, Chien AL. Rosacea is associated with chronic systemic diseases in a skin severity-dependent manner: results of a case-control study. J Am Acad Dermatol. 2015:73(4): 604-8. Epub 2015 Aug 6. PMID: 26256428
11. Woo YR, Lim JH, Cho DH, Park HJ. Rosacea: Molecular Mechanisms and Management of a Chronic Cutaneous Inflammatory Condition. Int J Mol Sci. 2016;17(9) Review. PMID: 2764916

12. Elewski BE, Draelos Z, Dréno B, Jansen T, Layton A, Picardo M. Rosacea global diversity and optimized outcome: proposed international consensus from the Rosacea International Expert Group. J Eur Acad Dermatol Venereol. 2011;25(2):188-200. Epub 2010 Jun 25. PMID: 20586834

13. Steinhoff M, Buddenkotte J, Aubert J, Sulk M, Novak P, Schwab VD, Mess C, Cevikbas F, Rivier M, Carlavan I, Déret S, Rosignoli C, Metze D, Luger TA, Voegel JJ. Clinical, cellular, and molecular aspects in the pathophysiology of rosacea. J Investig Dermatol Symp Proc. 2011;15(1):2-11. Review. PMID: 22076321

14. Del Rosso JQ, Gallo RL, Tanghetti E, Webster G, Thiboutot D. An evaluation of potential correlations between pathophysiologic mechanisms, clinical manifestations, and management of rosacea. Cutis. 2013;91(3 Suppl):1-8. Review. PMID: 23833998

15. Cribier B. Pathophysiology of rosacea: redness, telangiectasia, and rosacea. Ann Dermatol Venereol. 2011;138 Suppl 3:S184-91. PMID: 22183097

16. Yamasaki K, Gallo RL. Rosacea as a disease of cathelicidins and skin innate immunity. J Investig Dermatol Symp Proc. 2011;15(1):12-5. PMID: 22076322

17. Schauber J, Gallo RL. Antimicrobial peptides and the skin immune defense system. J Allergy Clin Immunol. 2008;122(2):261-6. Epub 2008 Apr 25. Review. PMID: 18439663

18. Vaughn AR, Notay M, Clark AK, Sivamani RK. Skin-gut axis: The relationship between intestinal bacteria and skin health. World J Dermatol. 2017:6(4):528.

19. Gallo RL, Nakatsuji T. Microbial symbiosis with the innate immune defense system of the skin. J Invest Dermatol. 2011;131(10):1974-80. Epub 2011 Jun 23. Review. PMID: 21697881

20. Ng QX, Soh AYS, Loke W, Lim DY, Yeo WS. The role of inflammation in irritable bowel syndrome (IBS). J Inflamm Res. 2018;11:345-9. PMID: 30288077

21. Holmes AD. Potential role of microorganisms in the pathogenesis of rosacea. J Am Acad Dermatol. 2013;69(6):1025-32. Epub 2013 Sep 5. PMID: 24011460

22. Parodi A, Paolino S, Greco A, Drago F, Mansi C, Rebora A, Parodi A, Savarino $\checkmark$. Small intestinal bacterial overgrowth in rosacea: clinical effectiveness of its eradication. Clin Gastroenterol Hepatol. 2008;6(7):759-64. Epub 2008 May 5. PMID: 18456568

23. Picardo M, Ottaviani M. Skin microbiome and skin disease: the example of rosacea. J Clin Gastroenterol. 2014;48(Suppl 1):S85-6. Review. PMID: 25291137

24. Zaidi AK, Spaunhurst K, Sprockett D, Thomason Y, Mann MW, Fu P, Ammons C, Gerstenblith M, Tuttle MS, Popkin DL. Characterization of the facial microbiome in twins discordant for rosacea. Exp Dermatol. 2018;27(3):295-8. PMID: 29283459

25. Di Nardo A, Holmes AD, Muto Y, Huang EY, Preston N, Winkelman WJ, Gallo RL. Improved clinical outcome and biomarkers in adults with papulopustular rosacea treated with doxycycline modified-release capsules in a randomized trial. J Am Acad Dermatol. 2016;74(6):1086-92. Epub 2016 Mar 5. PMID: 26951940

26. Del Rosso JQ, Webster GF, Jackson M, Rendon M, Rich P, Torok H, Bradshaw $M$. Two randomized phase III clinical trials evaluating anti-inflammatory dose doxycycline (40-mg doxycycline, USP capsules) administered once daily for treatment of rosacea. J Am Acad Dermatol. 2007;56(5):791-802. Epub 2007 Mar 23 PMID: 17367893

27. Wise RD. Submicrobial doxycycline and rosacea. Compr Ther. 2007;33(2):7881. PubMed PMID: 18004018

28. Cardwell LA, Alinia H, Moradi Tuchayi S, Feldman SR. New developments in the treatment of rosacea - role of once-daily ivermectin cream. Clin Cosmet Investig Dermatol. 2016:9:71-7. eCollection 2016. Review. PMID: 27051311

29. Coda AB, Hata T, Miller J, Audish D, Kotol P, Two A, Shafiq F, Yamasaki K, Harper JC, Del Rosso JQ, Gallo RL. Cathelicidin, kallikrein 5, and serine protease activity is inhibited during treatment of rosacea with azelaic acid 15\% gel. J Am Acad Dermatol. 2013;69(4):570-7. Epub 2013 Jul 18. PMID: 23871720

30. Del Rosso JQ. Evaluating the role of topical therapies in the management of rosacea: focus on combination sodium sulfacetamide and sulfur formulations. Cutis. 2004;73(1 Suppl):29-33. Review. PMID: 14959943 
31. Two AM, Wu W, Gallo RL, Hata TR. Rosacea: part II. Topical and systemic therapies in the treatment of rosacea. J Am Acad Dermatol. 2015;72(5):76170. quiz 771-2. Review. PMID: 25890456

32. van Zuuren EJ, Fedorowicz Z. Low-Dose Isotretinoin: An Option for Difficultto-Treat Papulopustular Rosacea. J Invest Dermatol. 2016;136(6):1081-3. Review PMID: 27212646

33. Mehrotra AN, Thomas Z, Goyal VP. Gastrointestinal side effects of tetracycline and its possible prevention by antifungal compounds. J Assoc Physicians India. 1970;18(7):627-9. PubMed PMID: 5473878

34. Chopra I, Roberts M. Tetracycline antibiotics: mode of action, applications, molecular biology, and epidemiology of bacterial resistance. Microbiol Mol Biol Rev. 2001;65(2):232-60. second page, table of contents. PubMed PMID: 11381101

35. Two AM, Hata TR, Nakatsuji T, Coda AB, Kotol PF, Wu W, Shafiq F, Huang EY, Gallo RL. Reduction in serine protease activity correlates with improved rosacea severity in a small, randomized pilot study of a topical serine protease inhibitor. J Invest Dermatol. 2014;134(4):1143-5. Epub 2013 Nov 8. PMID: 24213369

36. Triesscheijn M, Baas $P$, Schellens $J H$, Stewart FA. Photodynamic therapy in oncology. Oncologist. 2006;11(9):1034-44. Review. PMID: 17030646

37. Li X, Guo H, Tian Q, Zheng G, Hu Y, Fu Y, Tan H. Effects of 5-aminolevulinic acid-mediated photodynamic therapy on antibiotic-resistant staphylococcal biofilm: an in vitro study. J Surg Res. 2013;184(2):1013-21. Epub 2013 Apr 18 PMID: 23622723

38. Bryld LE, Jemec GB. Photodynamic therapy in a series of rosacea patients. J Eur Acad Dermatol Venereol. 2007;21(9):1199-202. PMID: 17894705

39. Lee JB, Bae SH, Moon KR, Na EY, Yun SJ, Lee SC. Light-emitting diodes downregulate cathelicidin, kallikrein and toll-like receptor 2 expressions in keratinocytes and rosacea-like mouse skin. Exp Dermatol. 2016;25(12):95661. Epub 2016 Oct 3. PMID: 27315464

40. Feldman SR, Huang WW, Huynh TT. Current drug therapies for rosacea: a chronic vascular and inflammatory skin disease. J Manag Care Spec Pharm. 2014;20(6):623-9. Review. PMID: 24856600

41. Asai Y, Tan J, Baibergenova A, Barankin B, Cochrane CL, Humphrey S, Lynde CW, Marcoux D, Poulin Y, Rivers JK, Sapijaszko M, Sibbald RG, Toole J, Ulmer M, Zip C. Canadian Clinical Practice Guidelines for Rosacea. J Cutan Med Surg. 2016;20(5):432-45. Epub 2016 May 17. Review. PMID: 27207355

42. Lee SY, You CE, Park MY. Blue and red light combination LED phototherapy for acne vulgaris in patients with skin phototype IV. Lasers Surg Med. 2007; 39(2):180-8. PMID: 17111415

43. Kwon HH, Lee JB, Yoon JY, Park SY, Ryu HH, Park BM, Kim YJ, Suh DH. The clinical and histological effect of home-use, combination blue-red LED phototherapy for mild-to-moderate acne vulgaris in Korean patients: a double-blind, randomized controlled trial. Br J Dermatol. 2013;168(5):108894. PMID: 23278295

44. Friedmann DP, Goldman MP, Fabi SG, Guiha I. The effect of multiple sequential light sources to activate aminolevulinic Acid in the treatment of actinic keratoses: a retrospective study. J Clin Aesthet Dermatol. 2014;7(9): 20-5. PMID: 25276272

45. Smith KR, Thiboutot DM. Thematic review series: skin lipids. Sebaceous gland lipids: friend or foe? J Lipid Res. 2008;49(2):271-81. Epub 2007 Nov 1. Review. PMID: 17975220

46. Charakida A, Seaton ED, Charakida M, Mouser P, Avgerinos A, Chu AC. Phototherapy in the treatment of acne vulgaris: what is its role? Am J Clin Dermatol. 2004:5(4):211-6. Review. PubMed PMID: 15301568

47. Ablon G. Phototherapy with Light Emitting Diodes: Treating a Broad Range of Medical and Aesthetic Conditions in Dermatology. J Clin Aesthet Dermatol. 2018;11(2):21-7. Epub 2018 Feb 1. Review. PMID: 29552272

48. Sorbellini E, Rucco M, Rinaldi F. Photodynamic and photobiological effects of light-emitting diode (LED) therapy in dermatological disease: an update. Lasers Med Sci. 2018;33(7):1431-9. Epub 2018 Jul 14. Review. PMID: 30006754

49. Pei S, Inamadar AC, Adya KA, Tsoukas MM. Light-based therapies in acne treatment. Indian Dermatol Online J. 2015;6(3):145-57. Review. PMID: 26009707

50. Dong Y, Zhou G, Chen J, Shen L, Jianxin Z, Xu Q, Zhu Y. A new LED device used for photodynamic therapy in treatment of moderate to severe acne vulgaris. Photodiagn Photodyn Ther. 2016;13:188-95. Epub 2015 Jun 23. PMID: 26116283

51. Schreiber S. A Novel Regimen for Perioral Dermatitis by Photodynamic Therapy. J Pharm Pharmacol. 2016;4:559-63.
52. Nybaek H, Jemec GB. Photodynamic therapy in the treatment of rosacea. Dermatology. 2005:211(2):135-8. PMID: 16088160

53. Katz B, Patel V. Photodynamic therapy for the treatment of erythema, papules, pustules, and severe flushing consistent with rosacea. J Drugs Dermatol. 2006;5(2 Suppl):6-8. PMID: 16485874

54. Cecic I, Sun J, Korbelik M. Role of complement anaphylatoxin C3a in photodynamic therapy-elicited engagement of host neutrophils and other immune cells. Photochem Photobiol. 2006;82(2):558-62. PMID: 16613513

55. Noborio R, Nishida E, Kurokawa M, Morita A. A new targeted blue light phototherapy for the treatment of acne. Photodermatol Photoimmunol Photomed. 2007:23(1):32-4. PMID: 17254034

56. Thiboutot D, Gollnick H, Bettoli V, Dréno B, Kang S, Leyden JJ, Shalita AR, Lozada VT, Berson D, Finlay A, Goh CL, Herane Ml, Kaminsky A, Kubba R, Layton A, Miyachi Y, Perez M, Martin JP, Ramos-E-Silva M, See JA, Shear N, Wolf J Jr, Global Alliance to Improve Outcomes in Acne. New insights into the management of acne: an update from the Global Alliance to Improve Outcomes in Acne group. J Am Acad Dermatol. 2009;60(5 Suppl):S1-50. Review. PMID: 19376456

57. Kumar A, Ghate V, Kim MJ, Zhou W, Khoo GH, Yuk HG. Antibacterial efficacy of 405, 460 and $520 \mathrm{~nm}$ light emitting diodes on Lactobacillus plantarum, Staphylococcus aureus and Vibrio parahaemolyticus. J Appl Microbiol. 2016; 120(1):49-56. PMID: 26481103

58. Cicarma E, Mørk C, Porojnicu AC, Juzeniene A, Tam T, Dahlback A, Moan J. Influence of narrowband UVB phototherapy on vitamin D and folate status. Exp Dermatol. 2010;19(8):e67-72. PMID: 19849714

\section{Publisher's Note}

Springer Nature remains neutral with regard to jurisdictional claims in published maps and institutional affiliations.
Ready to submit your research? Choose BMC and benefit from:
- fast, convenient online submission
- thorough peer review by experienced researchers in your field
- rapid publication on acceptance
- support for research data, including large and complex data types
- gold Open Access which fosters wider collaboration and increased citations
- maximum visibility for your research: over $100 \mathrm{M}$ website views per year
At BMC, research is always in progress.
Learn more biomedcentral.com/submissions 